\section{A Review of Pepino (Solanum muricatum Aiton) Fruit: A Quality Perspective}

\author{
Carolina Contreras, Mauricio González-Agüero, and Bruno G. Defilippi ${ }^{1}$ \\ Instituto de Investigaciones Agropecuarias, INIA-La Platina, Unidad de \\ Postcosecha, Santa Rosa 11610, Santiago, Chile
}

Additional index words. Solanaceae, quality, breeding, storage potential, climacteric, flavor

\begin{abstract}
Many attempts have been made to introduce pepinos in several countries. These efforts have involved breeding programs designed to adapt pepino plants to the respective climates and consumer preferences. However, low yields and the relatively small amount of information on the crop have played a negative role for the expansion of the pepino. Information on other features of the fruit (e.g., quality, physiology, and sensory attributes) is also scarce. Only a few studies provide useful data on pepino handling and storage potential; hence, there is not an adequate postharvest strategy to store this species. The objective of this review is to provide and discuss the available literature, with an emphasis on postharvest physiology aspects, and present 1) breeding for quality and how this has led to the development of the cultivars known today, 2) fruit physiology and quality, 3) handling and physiological disorders of pepino, and 4) highlight challenges for future research.
\end{abstract}

The pepino (Solanum muricatum Aiton), which is also referred to as pepino dulce in Spanish, has been described as a succulent, juicy, and sweet fruit that is used mainly in desserts, although some cultivars have been used in salads due to their higher acidity content and grassy flavor notes (RodríguezBurruezo et al., 2004a, 2011). In the 1990s, pepino was proposed as a physiological model of the texture or firmness changes that occur during maturation and ripening (Heyes et al., 1994), and in recent years, research has focused on genetic improvement of fruit quality (Levy et al., 2006; RodríguezBurruezo et al., 2004b, 2011). The pepino fruit is a diploid $(2 n=24)$ subtropical species and is also known as melon pear, melon shrub, or sweet cucumber. Native species from South America, more specifically from the Andes area of Peru and Chile, is widely distributed from Colombia to Bolivia (Daunay et al., 1995) (Fig. 1). The pepino fruit served as an important crop in Pre-Columbian Andean cultures, and it is a member of the Solanaceae family, which includes several important crops, such as tomatoes (S. lycopersicum), potatoes (S. tuberosum), and eggplants (S. melongena) among others (Prohens et al., 1996). Of the $\approx 1500$ species described in the Solanum genus (Weese and Bohs, 2007), pepino is one of the few that is domesticated and cultivated for food purposes (Daunay et al., 1995).

Interestingly, most pepino research has been conducted in New Zealand, Spain, and Israel through their respective breeding programs

Received for publication 22 Apr. 2016. Accepted for publication 22 July 2016 .

We gratefully acknowledge the financial support of CONICYT-Chile (Fondecyt project 3150082).

${ }^{1}$ Corresponding author. E-mail: bdefilip@inia.cl.
(Rodríguez-Burruezo et al., 2011). Unfortunately, pepino studies in the area of origin are scarce, and some reasons may lie in the fact that pepino is classified as a secondary fruit (Lizana and Levano, 1977), exotic or nontraditional crop, it has a low cultivated surface leading to reduced product availability in markets, and an insignificant economic importance relative to other major crops.

The aim of the present review is to critically summarize information of past and recent years on pepino breeding and postharvest physiology. In particular, research experiences about storage potential and quality are discussed.

\section{Pepino Crop}

The first documented use of S. muricatum is cited on pre-Inca ceramics displaying images of the fruit that date to at least 2000 years ago (Anderson et al., 1996). These authors also found that several unique haplotypes come from Colombia, suggesting that Colombia is the center of origin, based on the presumption that diversity is associated with the genetic origin. Therefore, Anderson et al. (1996) hypothesized that although the progenitor(s) is/are likely extinct, the closest wild ancestors are Solanum caripense and Solanum tabanoense because they are also found in Colombia and are both haplotype-associated with $S$. muricatum. Later, Blanca et al. (2007), by taking advantage of more sophisticated genetic tools, concluded that $S$. muricatum is a complicated cultigen and suggested that several wild species contributed to its origins and evolution. Part of the haplotype richness of the pepino may be attributed to hybridizations that occurred at several places and times, and to a lack of genetic and geographic barriers between cultivated and wild species of S. muricatum. Most importantly, these authors confirmed that the center of origin and diversity of pepino is Northern Ecuador/ Southern Colombia, and that pepino is closely related to species of the Caripensia series (Blanca et al., 2007).

Pepinos have been commercially and experimentally grown in several countries, including Australia (El-Zeftawi et al., 1988), Chile (Bravo and Arias, 1983), Colombia (Ruiz and Nuez, 1997), Peru, Ecuador (Bravo and Arias, 1983), Israel (Levy et al., 2006; Schaffer et al., 1989), New Zealand (Heyes et al., 1994; Redgwell and Turner, 1986), Turkey (Kola et al., 2015), United States (Ahumada and Cantwell, 1996), and Spain (Rodríguez-Burruezo et al., 2004b, 2011; Ruiz and Nuez, 1997; Ruiz et al., 1997), where cultivars have been developed for a Mediterranean climate.

For Chile, the cultivated surface is unknown, but the latest census data on planted farms reported 634 ha of pepino with the specific geographic area for this crop in the IV Region of Coquimbo (North of Chile) (ODEPA, Census of Agriculture, 2007). Production is mainly destined for the domestic market, and no export records are kept. There are currently no registered cultivars in Chile, although characteristic types are distinguished by fruit characteristics and/or by regions where pepinos are grown (Bravo and Arias, 1983). In general, clonal propagation by cuttings is the only mean of reproduction. This is also recommended for the cultivars released by Spain and other breeding programs, where each cultivar must be vegetatively propagated by stem cuttings to maintain the characteristics (Prohens et al., 2002; Rodríguez-Burruezo et al., 2004b). Although the plant is a perennial shrub, it is grown annually due to its frost sensitivity. Additionally, the plant is moderately tolerant to salinity (Ruiz and Nuez, 1997) and grows well under poor soil conditions (Bravo and Arias, 1983) (Fig. 2). However, pepino plants are sensitive to high temperatures, particularly during pollination and fruit setting (Burge, 1989).

One of the main problems of pepino fruit is its low organoleptic quality, which does not meet consumer standards as a result of poor handling and inadequate storage treatments (Huyskens-Keil et al., 2001; Rodríguez-Burruezo et al., 2011). Very few studies report harvest indices. For example, El-Zeftawi et al. (1988) recommend that pepinos should be golden yellow in color, with a firmness of $2 \mathrm{~kg} \cdot \mathrm{cm}^{-2}, 40 \%$ juice, and $9^{\circ}$ Brix. Today, consumers are more informed and interested in the consumption of exotic fruits of high nutritional value (RodríguezBurruezo et al., 2011). For example, pepino is described as a fruit with high water content (92\% fresh weight) and with excellent antioxidant properties; therefore, pepino is recommended for diabetic and sugar-free diets due to its low sugar content. Thus, pepino has a great potential for use as a natural antioxidant and beyond its nutritional 


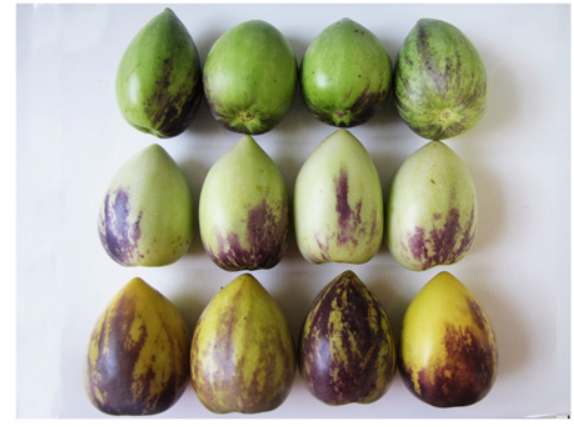

Fig. 1. Pepino fruit at three different maturity stages. Green (top), white (center), and yellow (bottom) ground color.

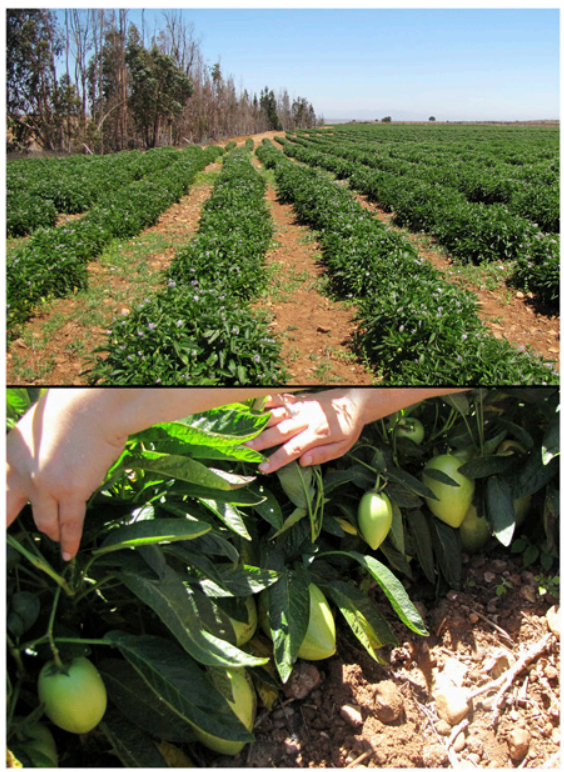

Fig. 2. Pepino field located in Ovalle, northern Chile (top). Developing pepino fruits (bottom).

potential (Redgwell and Turner, 1986; Sudha et al., 2012).

\section{Breeding for Quality}

In the 1990s, in their study on Solanum species, Daunay et al. (1995) suggested that some South American fruit species such as the pepino may be worth investigating as potential "new" species for inclusion in the European market. The authors noted a need of a breeding program for the adaptation of organoleptic requirements and agroclimatic conditions. Since then, several attempts to introduce pepinos into other markets have been made with modest success. Possible reasons for this limited use of pepinos include high sensitivity of fruit set to environmental conditions, especially to high temperatures, which affects its pollen viability; poor fruit quality (ripening is highly affected by temperature); the time required for fruit ripening; plant propagation; and a lack of exploration of its high degree of genetic diversity (Prohens et al., 1996).

A first attempt to introduce the pepino fruit to a new market was made by Spain in the early 1990s (Ruiz et al., 1992). As a result, two commercial pepino cultivars for the Mediterranean climate, 'Sweet Long' and 'Sweet Round', were developed as clone selections from seeds from northern and central Chilean accessions (Ruiz et al., 1997). Both cultivars were commercially cultivated in Spain, and their fruit were exported to several European countries. Thereafter, through the same breeding program, Spain selected hybrids with elevated levels of ascorbic acid, high firmness for increased resistance to bruising, round to ovoid fruit shapes (Prohens and Nuez, 1999), a crispy texture, and low sugar content for use in salads, as in the case of cv. Puzol (Prohens et al., 2002).

Other breeding studies have indicated that pepino presents high genotypic variation, confirming that the pepino is a highly variable species. In addition, dramatic phenotypic variations exist among pepino cultivars and ecotypes. Contrary to tomatoes, this phenotypic variation is correlated with a high variation at the molecular level, as demonstrated by phylogeny studies (Anderson et al., 1996; Rodríguez-Burruezo et al., 2003). Rodríguez-Burruezo et al. (2002) studied 26 different pepino clones and their quality parameters under autumn-winter and springsummer conditions. The authors found that under autumn-winter conditions, the fruit mass was genetically correlated with soluble solids concentration (SSC) and ascorbic acid levels, and that during spring-summer conditions, yield, SSC, and titratable acidity (TA) were all correlated. The genotypic variation found in these traits provided further possibilities for selecting pepino materials adapted to a Mediterranean climate as part of the breeding objectives of Spain. Autumnwinter clones were more adapted to cold conditions giving higher yields and fruit quality (Rodríguez-Burruezo et al., 2002). In regard to other traits (e.g., aroma), RodríguezBurruezo et al. (2004a) studied 10 different clones (4 parents with different flavors and 6 clone hybrids selected from segregating crossings among these parents) and concluded that a major fraction of volatiles is inheritable, thus demonstrating that aroma constitutes an important breeding trait. A strong relationship was found between the parents and hybrids for the concentration of individual volatiles. The cultivar Valencia is one of the most prominent breeding selections due to its quality characteristics such as high SSC content, vigor, high yield, intense yellow flesh, and early ripe fruit compared with other cultivars (Rodríguez-Burruezo et al., 2004b). Later, the cultivar Turia was released as the result of an intraspecific breeding program, and this new cultivar was developed for use in salads, unlike the Valencia cultivar, which was developed for use in desserts (Prohens et al., 2005). The breeding program conducted in Spain was mainly focused on quality (sweetness and aroma) and nutritional value (ascorbic acid content), and involved the use of a wide variety of genetic resources, clonal hybrids, and the introgression of genes of wild species, which translated into relatively high amplified fragment length polymorphism (AFLP)-estimated genetic distance and high heterozygosity (RodríguezBurruezo et al., 2011). In other countries, such as Israel, lesser-known cultivars have been developed. The breeding program in Israel released the following cultivars Pepo (the most widely cultivated cultivar in Israel), Becky, Rosy, Hannah, Nitza, and Tally (Levy et al., 2006). Although this program is not as extensive as the Spanish breeding program, the authors confirmed an improvement in quality traits (flavor and appearance) by breeding. Noteworthy, the authors found no correlation between high SSC and flavor acceptance. Other pepino cultivars mentioned in the literature are listed in Table 1; unfortunately, the breeding programs for some cultivars are unknown or not mentioned. Other pepino cultivars that are briefly mentioned in the literature include 'Lincoln Long', 'Golden Litestripe', 'Schmidt' (Prohens et al., 1996), 'Lima', 'Otavalo', and 'Quito' (Prohens et al., 2002).

As for Chile, Muñoz et al. (2014) recently reported a study based on the physiological fruit traits of 14 different Chilean ecotypes and found a moderate genetic variability in these seed-propagated selections. Most of the genetic variability among the ecotypes was related to fruit length, shape, mass, pulp firmness, and SSC. Recently, Herraiz et al. (2015a), in the Spanish breeding program, evaluated 58 morphological traits, using 14 pepino accessions (local Andean varieties and modern cultivars) and 8 wild relatives. High genetic diversity was found for both the cultivated and wild accessions. Fifty-five of the 58 traits were found to be variable, and only 3 were not found to vary (fruit with stripes, 2 locules inside the fruit, and seeds with no wings). Interestingly, local varieties originating from Chile are clustered closer to the modern varieties developed in Spain (Herraiz et al., 2015a).

\section{Postharvest Physiology of Pepino Fruit}

The pepino fruit has been described as a berry that develops on a cymose inflorescence (Gould et al., 1990). The fruit presents a simple sigmoid growth curve, and its maximum fruit size is reached $\approx 60 \mathrm{~d}$ after anthesis, corresponding to morphological stage 8 according to the $\mathrm{BBCH}$ (Biologische Bundesanstalt, Bundessortenamt und $\mathrm{CHemische}$ Industrie) numerical scale (Herraiz et al., 2015b), at which point the maximum sugar accumulation is also reached (Schaffer et al., 1989). The fruit takes between 30 and $60 \mathrm{~d}$ to grow to full size, after which, depending on the cv., can take between 7 and $25 \mathrm{~d}$ to fully ripen (Prohens and Nuez, 2001). Pepino fruit has been considered nonstarchy and a sucrose accumulator (Sánchez et al., 2000). Slightly more than $50 \%$ of the sweetness of pepino is attributed to its sucrose content, which increases dramatically during maturation (Kola et al., 2015; Redgwell and Turner, 1986; Sánchez et al., 2000). The average soluble solids content values reported by Redgwell and Turner (1986) and 
Table 1. Registered pepino cultivars documented in various research sources.

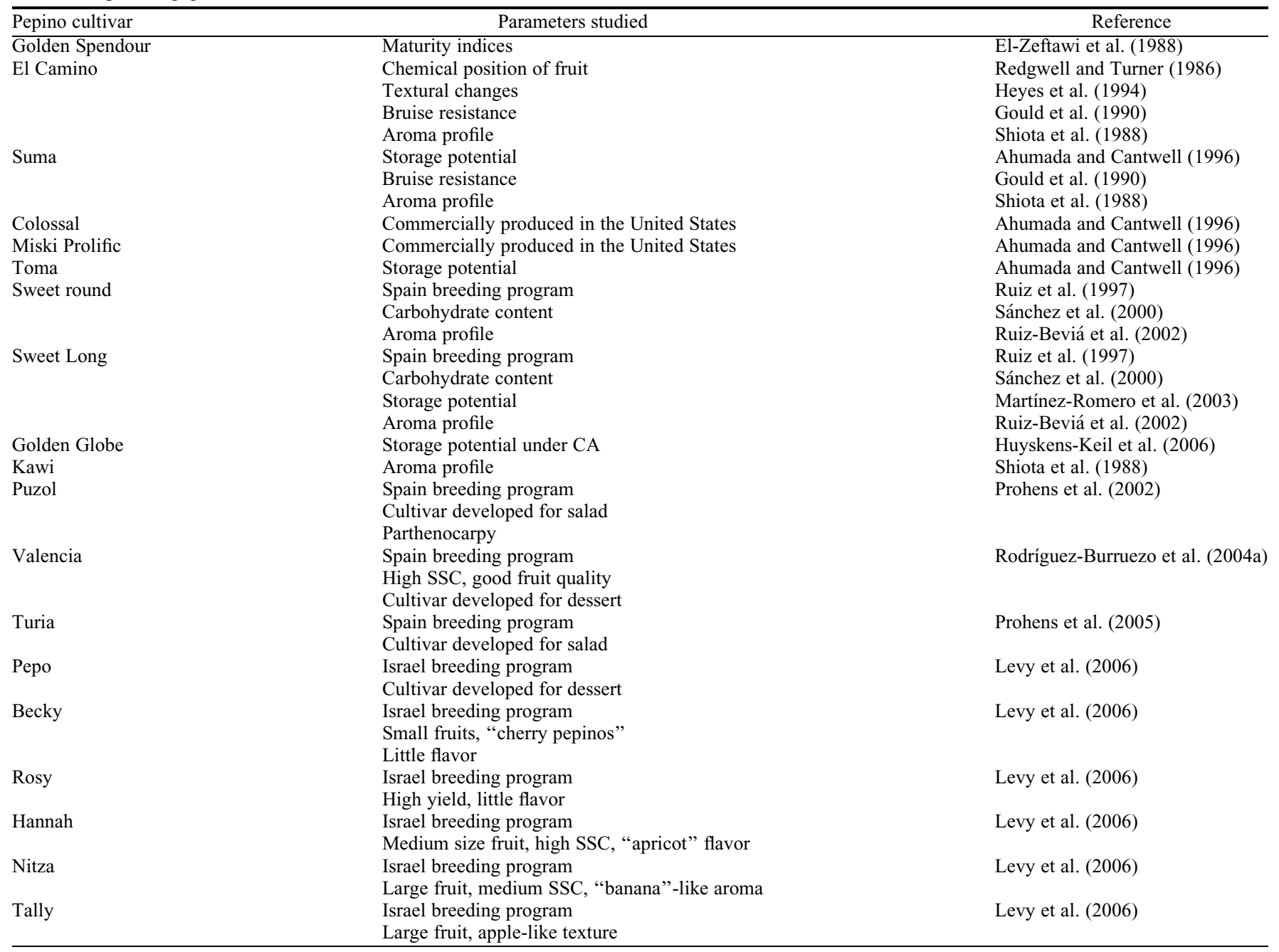

El-Zeftawi et al. (1988) range between 7.8\% and $9.6 \%$, and even lower values were reported by Sánchez et al. (2000), ranging between $5.2 \%$ and $8.6 \%$. Once pepinos reach near $9 \%$ on the plant ( 6 to 3 weeks before harvest), the soluble solids content stays low constant. Coincident with the literature, our data also showed a rather low content of sugars reaching a maximum of $9 \%$ during different developmental stages, and for fruit stored at $20{ }^{\circ} \mathrm{C}$ (data not shown). Our fruit were collected between January and Mar. 2015 from a commercial orchard located in Ovalle $\left(30^{\circ} 33^{\prime} 22.854^{\prime \prime} \mathrm{S} 71^{\circ} 38^{\prime} 43.004^{\prime \prime} \mathrm{W}\right.$, north of Chile).

Therefore, the fruit must be picked at or close to the desired stage of consumption because of its failure to improve flavor after picking (Sánchez et al., 2000). Glucose and fructose are also present in pepino, representing $28 \%$ and $18 \%$ of total sugars, respectively (Redgwell and Turner, 1986), but comparatively they increase less than sucrose (Huyskens-Keil et al., 2006; Schaffer et al., 1989). Sánchez et al. (2000) found an inverse relationship between water content and sugars that is highly dependent on environmental conditions. The authors found that early crops always had higher water content than late crops, and the inverse is true for sugars. Organic acids are almost exclusively represented by citric acid, which accounts for $91 \%$ of the total nonvolatile organic acids found in the fruit. Kola et al. (2015) reported in pepino cv. Miski that the citric acid content increased by $25 \%$ in ripe fruit compared with immature fruit. In addition, pepino contains vitamin $\mathrm{C}$ at higher levels $(48-68.8 \mathrm{mg} / 100 \mathrm{~g}$ fresh tissue) than normally found in most fruits (including citrus fruits) (Redgwell and Turner, 1986).

The first sign of pepino ripening is the appearance of purple strips. Conclusions on the climacteric (an increase or not in respiration during ripening classifies fruit as climacteric or nonclimacteric) of the pepino are not yet conclusive. The fruit has been described as both nonclimacteric (Ahumada and Cantwell, 1996; Harman et al., 1986; Heyes et al., 1994) and climacteric (Lizana and Levano, 1977). Heyes et al. (1994) reported accelerated color development and fruit softening when using propylene; however, ethylene production did not increase, and a transient respiratory rate was present. Ahumada and Cantwell (1996) reported very low ethylene production rates (only $>0.4 \mu \mathrm{L} \cdot \mathrm{kg}^{-1} \cdot \mathrm{h}^{-1}$ in fruit with severe decay) and lack of a climacteric respiratory pattern in the cv. Toma. Interestingly, ElZeftawi et al. (1988) applied ethephon in pepinos cv. Golden Spendour and concluded that pepinos require high concentrations of ethylene to stimulate ripening, likely with a small increase in respiration. Likewise, the authors showed that ethylene application to pepino triggered a change in color and fruit softening. Heyes et al. (1994) argue that "this was interpreted to suggest that pepinos are climacteric but other workers dispute this." Their data supported the conclusion that the pepino should be classified as a nonclimacteric fruit. Lizana and Levano (1977) reported a climacteric for pepinos with respiratory values ranging from 12.2 to $48.6 \mathrm{mg}$ $\mathrm{CO}_{2} / \mathrm{kg} / \mathrm{hr}$; however, ethylene production was not measured.

Ethylene and respiratory rates were measured in pepino fruits at different conditions: 1) during different phenological stages of development, from $10 \mathrm{~d}$ after fruit set until senescence; 2) commercial harvest maturity fruit stored a $7{ }^{\circ} \mathrm{C}$ for $14 \mathrm{~d}$ and then at $20^{\circ} \mathrm{C}$; and 3 ) commercial harvest maturity fruit stored at $20{ }^{\circ} \mathrm{C}$ for $16 \mathrm{~d}$. In all cases, fruit showed a moderate increase in autocatalytic ethylene after $65 \mathrm{~d}$ of development, and for storage after $10 \mathrm{~d}$ at $7{ }^{\circ} \mathrm{C}$ and after $5 \mathrm{~d}$ when 
stored at $20{ }^{\circ} \mathrm{C}$ (Fig. 3). The $\mathrm{CO}_{2}$ rate stayed rather constant the same day of the ethylene autocatalytic burst, and a modest respiratory peak appeared when stored at $20{ }^{\circ} \mathrm{C}$. However, additionally, we studied three different stages of maturity and no respiratory peak or autocatalytic burst was detected in any fruit (data not shown). These data coincide with the respiratory behavior that Kader (2002) classified pepino: a nonclimacteric fruit with a moderate production of $\mathrm{CO}_{2}(10-20 \mathrm{mg}$ $\mathrm{CO}_{2} / \mathrm{kg} / \mathrm{h}$ ) and low $\mathrm{C}_{2} \mathrm{H}_{4}$ production $(0.1-10$ $\mu \mathrm{L} \mathrm{C}_{2} \mathrm{H}_{4} / \mathrm{kg} / \mathrm{h}$ ).

Perhaps, physiological behavior varies with the cultivar, that is, some pepino cultivars are climacteric and others nonclimacteric. This variable ripening behavior has been extensively documented in other species, such as Asian pear, pepper, and tomato- rin and nor mutants (Grierson, 2013; Obando-Ulloa et al., 2008; Watkins, 2002).

\section{Fruit Quality}

Aroma. Aroma is defined as the odor of a food product (Meilgaard et al., 2007). The odor of a product is detected when volatiles enter the nasal passage (voluntarily or involuntarily) and are perceived by the olfactory system, whereas "aromatics are the volatiles perceived by the olfactory system from a substance in the mouth" (Meilgaard et al., 2007). Aroma is a critical component of perceived quality (Kader, 2002; Paliyath and Murr, 2008; Wills et al., 2007). The quality of a fruit is defined as the set of internal and external features inherent to the fruit, thus determining consumer acceptability (Paliyath and Murr, 2008). These characteristics, which are also known as "quality criteria" for the consumer include appearance (internal and/or external defects, size, color, and shape), texture, nutritional value, safety (Kader, 2002), and taste (Wills et al., 2007).

Aroma is a complex attribute to study due to the use of sensations that are translated into standard vocabulary, and the existence of a wide variety of volatiles. About 17,000 different types of odors are known, of which a trained person can detect 150-200 (Meilgaard et al., 2007). For example, an apple produces $\approx 270$ volatile compounds (Dimick and Hoskin, 1982), a tomato produces close to 400 volatiles (Buttery, 1993), and a strawberry $\approx 360$ volatiles (McFadden et al., 1965). These volatile chemicals fall into several categories including terpenes, esters, aldehydes, alcohols, and ketones. Esters, aldehydes, and alcohols are considered the most important aromatic perception for fresh fruits (Paliyath and Murr, 2008). The ripeness of the fruit will determine the level and type of the defined aroma compounds emitted by the fruit.

The aroma of a pepino fruit has been described as green, fresh, and reminiscent of melon and mango fruit (Shiota et al., 1988). A ripe pepino has a scent reminiscent of a cantaloupe melon, but when it is not fully ripe, it has a cucumber-like scent (Sánchez et al., 2000). The main volatile components identified in pepino were 3-methyl-2-buten-1-ol (a.k.a. prenol), 3-methyl-3-buten-1-ol, and their respective acetates, butyl acetate and (Z)-6-non-1-ol (Shiota et al., 1988). Interestingly, C9 compounds that have only been described in cucurbit species (Matsui et al., 2006) have also been found in pepino, and include nonanol, (Z)-6-nonenol, (Z)-6-nonenal, 2-nonanone, nonyl acetate, and $(Z)-6$-nonen-1-yl acetate. These C9 compounds undoubtedly account for the melon and cucumber-like fruit notes of pepino (Shiota et al., 1988). These authors detected at least 35 different volatiles in the flesh of 'El Camino', 'Suma', and 'Kawi', where the cv. Suma showed the greater amount of saturated and unsaturated C9 compounds, 'Kawi' the lowest level of total volatiles, and 'El Camino' showed the most pleasant aroma as it was found to include more unsaturated esters (Shiota et al., 1988). Other authors have reported changes in volatiles associated with different ripening stages. For example, a change during ripening from 3-methyl-2-buten-1-ol and 3-methyl-3-buten1-ol to their respective acetates has been found, increasing the aroma in the ripe fruits (Sánchez et al., 2000). Ruiz-Beviá et al. (2002) also showed that 3-methyl-2-buten-1-ol was the main volatile compound in pulp tissue, followed by 3-methyl-3-buten-1-ol, and their respective acetates. Interestingly, fruit peel samples showed low amounts of acetate and alcohols; however, the authors only quantified the four compounds listed above and did not mention the total volatile emissions from the fruit peel. Rodríguez-Burruezo et al. (2004a) studied the odor-contributing volatiles (OCVs) of 10 different pepino clones by GColfactometry-MS analyses. Of the more than 50 volatile compounds found in the aroma profile, 17 were found to contribute significantly to pepino aroma (OCVs). The authors classified these into three groups: fruity/fresh (acetates and prenol), green (C6 and C9 aldehydes), and exotic (lactones, mesifuran, and $\beta$-damascenone). Rodríguez-Burruezo et al. (2004b) quantified aroma compounds in $\mathrm{cv}$. Valencia and found fruity notes from the 3methyl-3-buten-yl acetate and 3-methyl-2buen-yl acetate esters to be the most abundant. The authors also found grassy notes of $\mathrm{C} 6$ compounds to be mainly derived from trans-2hexenal, and C9 compounds from 2,6-nonadienal and $(E)$-2-nonenal. Rodríguez-Burruezo et al. (2011) also identified 17 OCVs and reported 3-methylbut-2-en-1-yl acetate and 3-methylbut-3-en-1-yl acetate as the main compounds of fruity pepino selections, along with "exotic" notes such as $\beta$-damascenone, lactones, and mesifuran. For the green/vegetable aromas found for the other selections, predominant volatiles included aldehydes, such as hexanal and trans-2-hexenal, and several C9 compounds or nonenals.

Among the few studies conducted on the sensory field, Ruiz and Nuez (1997) performed an organoleptic test on different pepino clones after nutrition (focused on $\mathrm{K}^{+}$ among other nutrients) and salinity treatments. The sensory test showed that such treatments did not significantly affect aroma and that flavor was significantly improved as a result of an increased concentration of soluble solids.

Color. Often mentioned as the main quality criterion of the ripening stage, this character has been reported as an excellent harvest index for pepino (El-Zeftawi et al., 1988; Lizana and Levano, 1977). Although both ground and cover color (stripes) are used for harvesting purposes, ground color serves as a more robust index due to the strong pigmentation that the purple stripes undergo

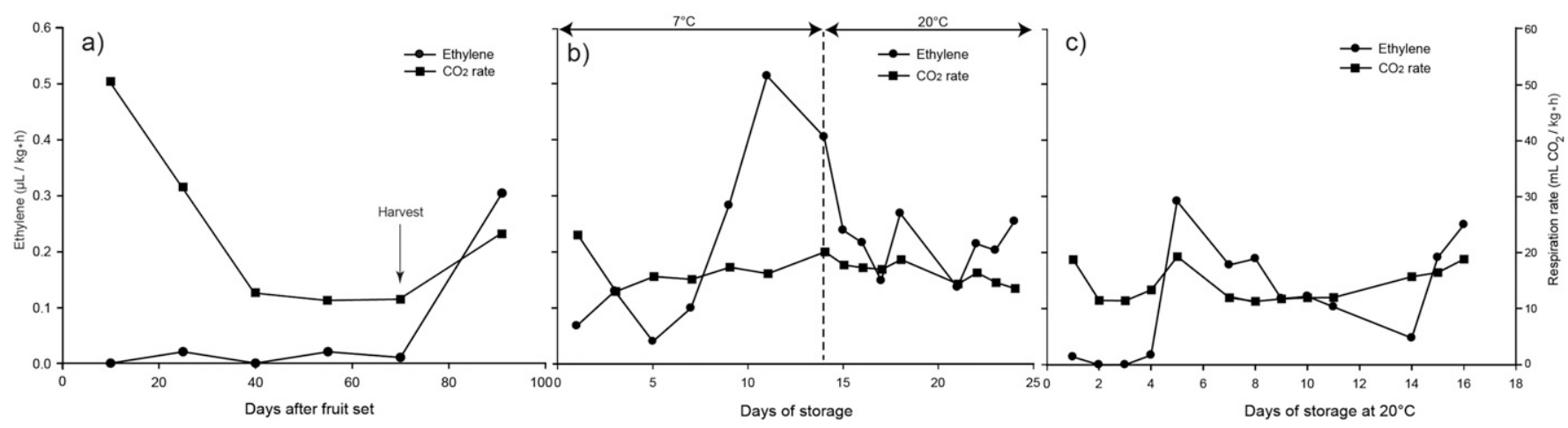

Fig. 3. Ethylene and respiratory patterns for pepino fruit during (A) developmental stages up to $65 \mathrm{~d}$ after fruit set, $(\mathbf{B})$ storage at $7{ }^{\circ} \mathrm{C}$ for $14 \mathrm{~d}$ and at $20^{\circ} \mathrm{C}$ for $10 \mathrm{~d}$, and $(\mathbf{C})$ storage at $20^{\circ} \mathrm{C}$ for $16 \mathrm{~d}$. For $(\mathbf{B})$ and $(\mathbf{C})$, each point represents the mean of 10 fruits of stage of maturity green ground color. Fruit were measured every $2 \mathrm{~d}$ under a static system. 
under direct or indirect sunlight (Lizana and Levano, 1977). Fruit harvest is carried out when ground color is green or white (Fig. 1). However, measuring pepino color has proven challenging as reported by Heyes et al. (1994). Variable ripening rates and the difficulty of a fully "objective" assessment of pepino maturity (areas free from purple stripes must be chosen), make subjective evaluation system of the whole fruit surface by the naked eye more reliable than instrumental measurements.

Under storage conditions, significant differences in fruit color development have been found. When stored in air at 5,8 , and $10{ }^{\circ} \mathrm{C}$, minor flesh color change was noted, but considerable variation was found for ground color (Lizana and Levano, 1977). Similar findings were reported in pepino by MartínezRomero et al. (2003) after storage treatments. These authors studied the cv. Sweet Long at three different maturity stages (green, light green, and yellow green) stored at 1,10 , or $20{ }^{\circ} \mathrm{C}$. Martínez-Romero et al. (2003) found significant differences in the yellow green stage stored at $1{ }^{\circ} \mathrm{C}$, but no significant color differences were found in the green and light green stages at different temperatures. They also reported changes in color due to external chilling injury $(\mathrm{CI})$, where more than $9 \%$ of the fruit turned brown in color after $28 \mathrm{~d}$ of storage. In contrast, for controlled atmosphere (CA) storage conditions, HuyskensKeil et al. (2006) reported that $\mathrm{CO}_{2}$ gas concentrations $\left(5 \% \mathrm{O}_{2}\right.$ and 5,15 , or $20 \%$ $\mathrm{CO}_{2}$ at 5 and $10{ }^{\circ} \mathrm{C}$ ) inhibited undesired color changes in mature and ripe pepinos for 21 and $14 \mathrm{~d}$, respectively, i.e., the fruits maintained color, regardless of the atmospheric composition. This observation is consistent with findings for various other commodities (Kader, 2002), where high $\mathrm{CO}_{2}$ concentrations led to the retention of color intensity (Huyskens-Keil et al., 2006).

Ambiguous results have been reported in reference to external treatments involving ethylene. For instance, Ahumada and Cantwell (1996) found ethylene to accelerate external color development in low maturity fruit, whereas El-Zeftawi et al. (1988), using postharvest ethephon dipping, found little effect on fruit color.

Texture. Firmness is considered one of the main quality attributes of fruits in terms of consumer acceptability. In pepino, a loss of firmness has been determined to result from a progressive disassembling of the cell wall and a loss of cellular adhesion; in turn, pulp density decreases during ripening, and cellto-cell contact areas likely decline, whereas intercellular spaces increase during ripening (Heyes et al., 1994). Likewise, polygalacturonase (PG) and pectinmethylesterase (PME) enzymes, which have been widely studied in many other fruit species, exhibit the same behavior in pepino, with increasing enzymatic activity during ripening (Heyes et al., 1994; Schaffer et al., 1989). As expected, higher temperatures and more advanced stages of ripening result in higher rates of softening in pepino fruit.
Lizana and Levano (1977) reported a dramatic loss in firmness after $30 \mathrm{~d}$ of storage, finding values of $3 \mathrm{lb}$ after $60 \mathrm{~d}$ of storage at 5,8 , and $10^{\circ} \mathrm{C}$. Three maturity stages were evaluated yellow (M1), green yellow (M2), and green white (M3). All pepinos stored at 20,10 , and $1{ }^{\circ} \mathrm{C}$ showed a significant decrease during storage, especially during the first 2 weeks (Martínez-Romero et al., 2003). However, these authors found that for fruits stored at $10^{\circ} \mathrm{C}$, the loss of firmness was lower than for those stored at 1 and $20{ }^{\circ} \mathrm{C}$ at any ripening stages, and the greatest firmness losses were found at $1{ }^{\circ} \mathrm{C}$, likely as a consequence of the CI. The beneficial effects of high $\mathrm{CO}_{2}$ concentrations in reducing fruit softening for mature pepinos are presumably due to the inhibition of cell wall-degrading enzyme activities, e.g., PME and PG, as reported by Heyes et al. (1994). CA studies showed that mature pepino fruits exhibited significantly higher firmness than ripe fruits under all tested CA storage conditions until $14 \mathrm{~d}$ of storage (Huyskens-Keil et al., 2006). Plant nutrition levels have also been examined as a factor that contributes to fruit firmness. Ruiz and Nuez (1997) determined that nutrition treatments (focused on $\mathrm{K}^{+}$ among other nutrients) did not significantly affect pepino fruit texture

Another parameter closely related to firmness is bruising. The propensity of pepino to show bruising after handling and transport also has become a limiting factor in its commercial development (Gould et al., 1990). Gould et al. (1990) documented that pepinos show a dark "waterlogged" or "soggy" area after compressive force. These authors studied two cultivars (Suma and El Camino) and 16 selections of pepino, determining that softer fruit are more likely to show bruise injury than a firmer fruit. Thus, bruising increases as a fruit ripens. The Suma cultivar was identified as the most susceptible to bruising, whereas El Camino fruit presented a moderate susceptibility. Bruising is associated with the size and compactness of exocarp cells. For example, the 'Suma' fruit possesses larger air pockets, providing little resistance to an applied load, whereas for resistant selections, air spaces are smaller, and the stress is dispersed over a larger surface area, thus decreasing the average loading transmitted onto mesocarp cells (Gould et al., 1990). For shipping purposes, pepinos are harvested at an early ripening stage, because they are highly sensitive to bruising (Huyskens-Keil et al., 2006).

\section{Postharvest Handling and Physiological Disorders}

One of the first reports on pepino storage potential was conducted by Lizana and Levano (1977). These authors studied the postharvest behavior of pepino fruit at three maturity stages at $-5,0,3,5,12$, and $18{ }^{\circ} \mathrm{C}$, and also determined the maximum potential storage period by studying pepinos up to $75 \mathrm{~d}$ of storage. The lowest temperatures $(-5$ and $0{ }^{\circ} \mathrm{C}$ ) induced intense browning, producing inedible soft fruit. Temperatures of 1 and $3{ }^{\circ} \mathrm{C}$ favored superficial injury (similar to superficial scald on apple and pears) with brown sunken spots that were usually isolated, and 0.1 to $0.3 \mathrm{~mm}$ in depth. They found 5,8 , and $10^{\circ} \mathrm{C}$ to be optimal temperatures for pepino storage. Another physiological disorder reported by Lizana and Levano (1977) was internal breakdown, characterized by the browning of ripened fruit after prolonged cold storage. Ahumada and Cantwell (1996) studied pepino cv. Toma at different temperatures and maturity stages for four weeks, where the most successful temperature treatment for all fruit maturities was $7.5-10{ }^{\circ} \mathrm{C}$. Less ripe fruits stored at $<5{ }^{\circ} \mathrm{C}$ were severely damaged with external discoloration. Physiological disorders reported by Ahumada and Cantwell (1996) included CI that caused internal and external discoloration, and decay symptoms due to a dark brown rot starting at the stem and eventually developing within the fruit pulp. Huyskens-Keil et al. (2000) studied physiological changes in pepino at $5{ }^{\circ} \mathrm{C}$ and $18{ }^{\circ} \mathrm{C}$ for three different maturity stages, and concluded that changes in external and internal quality only occurred up to $14 \mathrm{~d}$ of storage, thereafter pepino quality remained almost constant. MartínezRomero et al. (2003) studied pepino cv. Sweet Long to evaluate physiological changes under chilling and nonchilling temperatures $\left(1,10\right.$, and $\left.20^{\circ} \mathrm{C}\right)$ at three different maturities for $28 \mathrm{~d}$. The fruit storage potential for the riper stage was 1-2 weeks, whereas for the other fruit stored at 10 or $20^{\circ} \mathrm{C}$, it was 4 and 3 weeks, respectively. MartínezRomero et al. (2003) also reported internal CI expressed as flesh translucency associated with internal browning. External CI was observed as brown spots on the skin where the most susceptible fruit were the riper stage stored at $1{ }^{\circ} \mathrm{C}$.

Other studies that have involved storage technologies, such as film packaging, CA, and modified atmosphere (MA), have found that changes in gas concentrations improve pepino fruit storability and quality as in the case of other fruits (Kader, 2002). HuyskensKeil et al. (2001) studied the performance of edible coating (sucrose ester) and film packaging (plastic food container) on pepino fruits stored at 5 and $20{ }^{\circ} \mathrm{C}$. Although both postharvest treatments were successful, the film treatment had better effects on mass loss, prevented undesirable color changes and softening. Huyskens-Keil et al. (2006) investigated the postharvest quality of pepino 'Golden Globe' under CA combinations of $5 \% \mathrm{O}_{2}$ and 5,15 , or $20 \% \mathrm{CO}_{2}$ for $21 \mathrm{~d}$ at 5 and $10{ }^{\circ} \mathrm{C}$. The authors concluded that postharvest quality was strongly dependent on the ripening stage, that is, mature pepino showed higher retention of texture and color, and better storability, whereas the ripe stage was recommended for ready-to-eat fresh market fruit. In reference to Chile, Galletti et al. (2006) studied the storage potential of pepino fruit in MA (3\% to $5 \% \mathrm{CO}_{2}$ and $9 \%$ to $14 \%$ $\mathrm{O}_{2}$ ) for 21 and $35 \mathrm{~d}$ at $8{ }^{\circ} \mathrm{C}$. Two maturation stages "green" and "yellow green" were 
stored under MA, and the main effects resulted in color delay, firmness retention, and reduced water loss. As Huyskens-Keil et al. (2006) found, storage benefits of MA also depended on the fruit ripening stage. In this case, Galletti et al. (2006) reported better results in maturation stage "green," suggesting that mature green fruits have more storage potential. Despite quality-related benefits associated with MA, Galletti et al. (2006) did not recommend the use of MA, which reached up to $5 \% \mathrm{CO}_{2}$, due to the presence of "off-flavors" after storage. Neither CA nor MA studies reported on the presence of postharvest physiological disorders.

\section{New Perspectives and Challenges}

One of the main challenges related to the use of this crop is the identification of wild genotypes that are still present in South America and the subsequent development of new cultivars. Herraiz et al. (2015a) recently reported that the genetic diversity levels are still very high in Ecuador, southern Colombia, and northern Peru, thus forming a major reservoir of genetic material. This feature renders the Andean region a rich source of genetic material for future breeding programs. In regard to phenotypic diversity, some studies have focused on the characterization of ecotypes, and major efforts have focused on the phenotypic characterization of specific traits of agronomic interest (Muñoz et al., 2014). The availability of standardized morphological characterization data is essential for the development of breeding programs on this crop.

Breeding for higher yields and fruit quality adapted to markets have resulted in the development of modern varieties with larger and elongated fruits (Herraiz et al., 2015a). These fruits are more suitable for shipping, because they pack better in boxes resulting in fewer bruises than the round fruit. However, the need to develop sweeter fruit cultivars is high, particularly for European market demands, where sugar contents of $8 \%$ are considered to be too low by consumers (Kola et al., 2015).

Other challenges facing the continued improvement of pepino storage performance have taken on a greater significance: the development of cultivars suitable for handling, transport, and long-term storage. The study and use of storage technologies such as $\mathrm{CA}, \mathrm{MA}$, and film packaging has been carried out in recent years. Unfortunately, long-term storage seems to be a challenge for pepino fruit, which has proven to be very sensitive to temperatures lower than $5{ }^{\circ} \mathrm{C}$ (Lizana and Levano, 1977) and can be damaged under CA conditions (data not shown). Better strategies and/or recommendations to store pepino are still needed. It is currently known that pepinos store well at $7{ }^{\circ} \mathrm{C}$ for $40 \mathrm{~d}$ under regular atmosphere $\left(21 \% \mathrm{O}_{2}, 0 \% \mathrm{CO}_{2}\right)$ (data not shown). Given the formation of CA injury, current studies on several CA combinations are being conducted by the authors of this review for the development of an adequate storage protocol. Although it can take several years to establish a storage protocol due to the validation of fruits harvested in different years, from different plants (yearly crops), or from different inflorescence trusses, a suitable postharvest protocol must be developed.

\section{Conclusion}

Pepino, a Solanaceae fruit with a unique sweet taste, has received modest attention from the scientific community over the years. The commercial production of this species has also been neglected, mainly due to a lack of information on storage and handling, which has resulted in poor quality outcomes for consumers. Nonetheless, pepinos present great potential as a horticultural crop due to their plasticity in adapting to different agroclimatic conditions and for their quality characteristics, especially in terms of flavor. Fruit maturity is also important for fruit quality at the consumer level since it is affecting several quality attributes, such as appearance, texture, and flavor. Depending on the maturation stage, the storage conditions have a strong impact in the shelf life of pepino fruit, being the loss of firmness the main limiting factor for riper stages. Further research on this species is needed, particularly at the molecular level, and should take advantage of the fact that the genomes of its closest relatives (e.g., tomato and potato) have been already sequenced. Thus, future efforts should focus on quality and storability aspects.

\section{Literature Cited}

Ahumada, M. and M. Cantwell. 1996. Postharvest studies in pepino dulce (Solanum muricatum Ait.): Maturity at harvest and storage behavior. Postharvest Biol. Technol. 7:129-136.

Anderson, G., R. Jansen, and Y. Kim. 1996. The origin and relationships of the pepino, Solanum muricatum (Solanaceae): DNA restriction fragment evidence. Econ. Bot. 50:369-380.

Blanca, J., J. Prohens, G. Anderson, E. Zuriaga, J. Cañizares, and F. Nuez. 2007. AFLP and DNA sequence variation in Andean domesticate, pepino (Solanum muricatum, Solanaceae): Implications for evolution and domestication. Amer. J. Bot. 94:1219-1229.

Bravo, A. and E. Arias. 1983. Cultivo del pepino dulce. El Campesino 114:15-33.

Burge, G.K. 1989. Fruit set in the pepino (Solanum muricatum Ait.). Sci. Hort. 41:63-68.

Buttery, R.G. 1993. Quantitative and sensory aspects of flavor of tomato and other vegetables and fruits, p. 259-286. In: T.E. Acree and R. Teranishi (eds.). Flavor science: Sensible principles and techniques. Amer. Chem. Soc., Washington, DC.

Daunay, M., F. Rousselle-Bourgeois, R. Lester, and J. Peron. 1995. Known and less known Solanum species for fresh market. Acta Hort. 412:293-305.

Dimick, P. and J. Hoskin. 1982. Review of apple flavor-state of the art. Crit. Rev. Food Sci. Nutr. 18:387-409.

El-Zeftawi, B., L. Brohier, L. Dooley, F. Goubran, R. Holmes, and B. Scott. 1988. Some maturity indices for tamarillo and pepino fruits. J. Hort. Sci. 63:163-169.

Galletti, L., H. Berger, D. Drouilly, and A. Lizana. 2006. Atmósfera modificada en fruto de pepino dulce. IDESIA (Chile) 24:35-40.
Gould, K., K. Hammett, and S. Steinhagen. 1990. Mechanism of bruise resistance in pepino (Solanum muricatum) fruit. Ann. Bot. (Lond.) 66:155-161.

Grierson, D. 2013. Ethylene and the control of fruit ripening, p. 43-73. In: G. Seymour, M. Poole, J. Giovanonni, and G. Tucker (eds.). The molecular biology and biochemistry of fruit ripening. Chapman and Hall press, London, UK.

Harman, J., M. Hogg, and F. Horne. 1986. Maturity and quality indices for pepino fruit. HortScience 21:129 (abstr.).

Herraiz, F., S. Vilanova, I. Andújar, D. Torrent, M. Plazas, P. Gramazio, and J. Prohens. 2015a. Morphological and molecular characterization of local varieties, modern cultivars and wild relatives of an emerging vegetable crop, the pepino (Solanum muricatum), provides insight into its diversity, relationships and breeding history. Euphytica 206:301-318.

Herraiz, F., S. Vilanova, M. Plazas, P. Gramazio, I. Andújar, A. Rodríguez-Burruezo, A. Fita, G. Anderson, and J. Prohens. 2015b. Phenological growth stages of pepino (Solanum muricatum) according to the BBCH scale. Sci. Hort. 183:1-7.

Heyes, J., F. Blaikie, C. Downs, and D. Sealey. 1994. Textural and physiological changes during pepino (Solanum muricatum Ait.) ripening. Sci. Hort. 58:1-15.

Huyskens-Keil, S., H. Prono-Widayat, P. Lüdders, and M. Schreiner. 2006. Postharvest quality of pepino (Solanum muricatum Ait.) fruit in controlled atmosphere storage. J. Food Eng. 77:628-634.

Huyskens-Keil, S., H. Prono-Widayat, P. Lüdders, M. Schreiner, and P. Peters. 2000. Physiological changes of pepino (Solanum muricatum Ait.) during maturation and ripening. Acta Hort. 531:251-256.

Huyskens-Keil, S., H. Prono-Widayat, M. Schreiner, and P. Peters. 2001. Effect of surface coating and film packaging on the keeping quality of solanaceous crops (Solanum muricatum Ait., Solanum quitoense Lam.). Acta Hort. 553:621-625.

Kader, A. 2002. Quality and safety factors: Definition and evaluation for fresh horticultural crops, p. 279-285. In: A. Kader (ed.). Postharvest technology of horticultural crops. Oakland, CA.

Kola, O., M. Simsek, H. Duran, and H. Bozkir. 2015. HPLC determination of carotenoid, organic acid, and sugar content in pepino (Solanum muricatum) fruit during the ripening period. Chem. Nat. Compd. 51:132-136.

Levy, D., N. Kedar, and N. Levy. 2006. Pepino (Solanum muricatum Aiton): Breeding in Israel for better taste and aroma. Isr. J. Plant Sci. 54:205-213.

Lizana, L. and B. Levano. 1977. Caracterización y comportamiento de post-cosecha del pepino dulce Solanum muricatum. Ait. Proc. Trop. Reg. Am. Soc. Hort. Sci. 21:11-15.

Martínez-Romero, D., M. Serrano, and D. Valero. 2003. Physiological changes in pepino (Solanum muricatum Ait.) fruit stored at chilling and non-chilling temperatures. Post. Biol. Technol. 30:177-186.

Matsui, K., A. Minami, E. Hornung, H. Shibata, K. Kishimoto, V. Ahnert, H. Kindl, T. Kajiwara, and I. Feussner. 2006. Biosynthesis of fatty acid derived aldehydes is induced upon mechanical wounding and its products show fungicidal activities in cucumber. Phytochemistry 67:649-657.

McFadden, W., R. Teranishi, J. Corse, D. Black, and T. Monday. 1965. Volatiles from strawberries. II. Combined mass spectrometry and gas chromatography on complex mixtures. J. Chromatography $18: 10-19$. 
Meilgaard, C., G. Civille, and B. Carr. 2007. Sensory attributes and the way we perceive them, p. 7-24. In: Sensory evaluation techniques. Taylor Francis Group CRC Press, FL.

Muñoz, C., R. Pertuzé, M. Balzarini, C. Bruno, and A. Salvatierra. 2014. Genetic variability in Chilean pepino (Solanum muricatum Aiton) fruit. Chil. J. Agr. Res. 74:143-147.

Obando-Ulloa, J., E. Moreno, J. García-Mas, B. Nicolai, J. Lammertyn, A. Monforte, and J. Fernández-Trujillo. 2008. Climacteric or nonclimacteric behavior in melon fruit. 1. Aroma volatiles. Post. Biol. Technol. 49:27-37.

ODEPA, Census of Agriculture. 2007. Vegetables. Chilean Department of Agriculture. 11 Nov. 2015. <http://icet.odepa.cl/>.

Paliyath, G. and D. Murr. 2008. Common fruits, vegetables, flowers, and their quality, p. 8-18. In: G. Paliyath, D. Murr, A. Handa, and S. Lurie (eds.). Postharvest biology and technology of fruits, vegetables, and flowers. Markono Print Media Pte. Ltd., Singapore.

Prohens, J., M. Leiva-Brondo, A. Rodríguez-Burruezo, and F. Nuez. 2002. 'Puzol': A facultatively parthenocarpic hybrid of pepino (Solanum muricatum). HortScience 37:418-419.

Prohens, J. and F. Nuez. 1999. Strategies for breeding a new greenhouse crop, the pepino (Solanum muricatum Aiton). Can. J. Plant Sci. 79:269-275.

Prohens, J. and F. Nuez. 2001. Improvement of mishqui (Solanum muricatum) earliness by selection and ethephon applications. Sci. Hort. 87:247-259.

Prohens, J., A. Rodríguez-Burruezo, and F. Nuez. 2005. Utilization of genetic resources for the introduction and adaptation of exotic vegetable crops: The case of pepino (Solanum muricatum). Euphytica 146:133-142.
Prohens, J., J. Ruiz, and F. Nuez. 1996. The pepino (Solanum muricatum, Solanaceae). A "new" crop with a history. Econ. Bot. 50:355-368.

Redgwell, R. and N. Turner. 1986. Pepino (Solanum muricatum): Chemical composition of ripe fruit. J. Sci. Food Agr. 37:1217-1222.

Rodríguez-Burruezo, A., J. Prohens, and F. Nuez. 2002. Genetic analysis of quantitative traits in pepino (Solanum muricatum) in two growing seasons. J. Amer. Soc. Hort. Sci. 127:271-278.

Rodríguez-Burruezo, A., J. Prohens, and F. Nuez. 2003. Performance of hybrid segregating populations of pepino (Solanum muricatum) and its relation to genetic distance among parents. J. Hort. Sci. Biotechnol. 78:911-918.

Rodríguez-Burruezo, A., H. Kollmannsberger, J. Prohens, S. Nitz, and F. Nuez. 2004a. Analysis of the volatile aroma constituents of parental and hybrid clones of pepino (Solanum muricatum). J. Agr. Food Chem. 52:5663-5669.

Rodríguez-Burruezo, A., J. Prohens, and F. Nuez. 2004b. 'Valencia': A new pepino (Solanum muricatum) cultivar with improved fruit quality. HortScience 39:1500-1502.

Rodríguez-Burruezo, A., J. Prohens, and A. Fita. 2011. Breeding strategies for improving the performance and fruit quality of the pepino (Solanum muricatum): A model for the enhancement of underutilized exotic fruits. Food Res. Intl. 44:1927-1935.

Ruiz, J., F. Nuez, M. Amurrio, A. de Ron, and M. Fueyo. 1992. Adaptation of the pepino (Solanum muricatum Ait.) in Spain. Acta Hort. 318:213-216.

Ruiz, J. and F. Nuez. 1997. The pepino (Solanum muricatum Ait.): An alternative crop for areas affected by moderate salinity. HortScience 32:649-652.
Ruiz, J., J. Prohens, and F. Nuez. 1997. 'Sweet Round' and 'Sweet Long': Two pepino cultivars for Mediterranean climates. HortScience 32:751-752.

Ruiz-Beviá, F., A. Font, A. García, P. Blasco, and J. Ruiz. 2002. Quantitative analysis of the volatile aroma components of pepino fruit by purgeand-trap and gas chromatography. J. Sci. Food Agr. 82:1182-1188.

Sánchez, M., M. Cámara, J. Prohens, J. Ruiz, E. Torija, and F. Nuez. 2000. Variation in carbohydrate content during ripening in two clones of pepino. J. Sci. Food Agr. 80:1985-1991.

Schaffer, A., I. Rylski, and M. Fogelman. 1989 Carbohydrate content and sucrose metabolism in developing Solanum muricatum fruits. Phytochemistry 3:737-739.

Shiota, H., H. Young, V. Paterson, and M. Irie. 1988. Volatile aroma constituents of pepino fruit. J. Sci. Food Agr. 43:343-354.

Sudha, G., M. Sangeetha, P. Rajan, B. Shree, and S. Vadivukkarasi. 2012. Antioxidant activity of ripe and unripe pepino fruit (Solanum muricatum Aiton). J. Food Sci. 77:C1131-C1135.

Watkins, C. 2002. Ethylene synthesis, mode of action, consequences and control, p. 180-224. In: M. Knee (ed.). Fruit quality and its biological basis. CRC press, Boca Raton, FL.

Weese, T. and L. Bohs. 2007. A three-gene phylogeny of the genus Solanum (Solanaceae). Syst. Bot. 32:445-463.

Wills, R., B. McGlasson, D. Graham, and D. Joyce. 2007. Evaluation and management of quality, p. 159-187. In: R. Will (ed.). Postharvest: An introduction to the physiology and handling of fruit, vegetables and ornamentals. University of New South Wales Press Ltd., Sydney, Australia. 